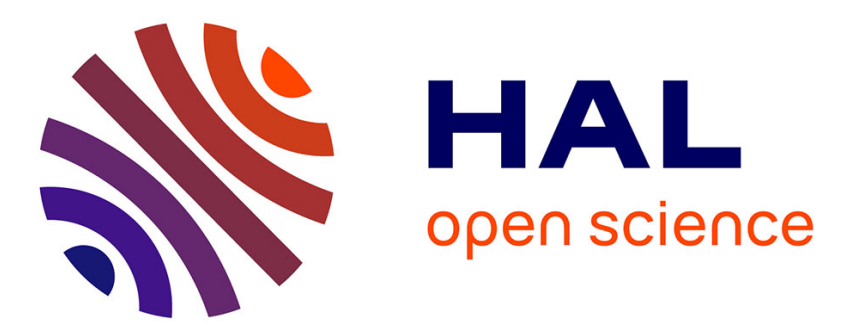

\title{
Diversity and Distribution of Leaf Mining Insects on Birches (Betula spp.) in Siberia
}

Natalia Kirichenko, Vladimir M. Petko, Emmanuelle Magnoux, Carlos

Lopez-Vaamonde

\section{- To cite this version:}

Natalia Kirichenko, Vladimir M. Petko, Emmanuelle Magnoux, Carlos Lopez-Vaamonde. Diversity and Distribution of Leaf Mining Insects on Birches (Betula spp.) in Siberia. Entomological Review, 2017, 97 (2), pp.183-198. 10.1134/S0013873817020051 . hal-01603813

\section{HAL Id: hal-01603813 \\ https://hal.science/hal-01603813}

Submitted on 25 May 2020

HAL is a multi-disciplinary open access archive for the deposit and dissemination of scientific research documents, whether they are published or not. The documents may come from teaching and research institutions in France or abroad, or from public or private research centers.
L'archive ouverte pluridisciplinaire HAL, est destinée au dépôt et à la diffusion de documents scientifiques de niveau recherche, publiés ou non, émanant des établissements d'enseignement et de recherche français ou étrangers, des laboratoires publics ou privés.

\section{다(1)(2)}

Distributed under a Creative Commons Attribution - ShareAlike| 4.0 International 


\title{
Diversity and Distribution of Leaf Mining Insects on Birches (Betula spp.) in Siberia
}

\author{
N. I. Kirichenko ${ }^{a, b, c^{* *}}$, V. M. Petko ${ }^{a^{* * *}}$, E. Magnoux ${ }^{c^{* * * *}}$, and C. Lopez-Vaamonde ${ }^{c^{* * * * *}}$ \\ ${ }^{a}$ Sukachev Institute of Forest, Siberian Branch of Russian Academy of Sciences, Federal Research Center \\ “Krasnoyarsk Science Center SB RAS,” Krasnoyarsk, 660036 Russia \\ e-mail:*nkirichenko@yahoo.com,**vladpetko@gmail.com \\ ${ }^{b}$ Siberian Federal University, Krasnoyarsk, 660041 Russia \\ ${ }^{c}$ French National Institute for Agricultural Research (INRA), Orléans, F-45075 France \\ e-mail:***emmanuelle.magnoux@orleans.fr,****carlos.lopezvaamonde@inra.fr \\ Received June 15, 2016
}

\begin{abstract}
The diversity and distribution of leaf mining insects developing on birches (Betula spp.) in Siberia were reviewed based on published records and our observations. Analysis of the literature revealed 52 species of leaf miners recorded as feeding on different Betula species in Siberia. Among them, three species were listed under different names and six species were erroneously recorded as birch consumers. Thus, the revised list of birch leaf miners contains 44 species. Five moth and four sawfly species are mentioned in the literature as pests of Betula. Four sawflies are known to be invasive in North America. Our collections comprised 25 species, including the micro-moth Stigmella continuella (Lepidoptera, Nepticulidae), a new species for Siberia found in Novosibirsk. Immature stages of 15 species were identified using DNA barcoding. Twenty species were recorded from several regions of Siberia for the first time. The dominant group is Lepidoptera (31 species), followed by Coleoptera (7), Hymenoptera (5), and Diptera (1). Two-thirds of all the known leaf miners develop exclusively on birches; the remaining species also colonize alders (Alnus, Betulaceae), some Rosaceae, Salicaceae, and Ulmaceae. In our observations, the majority of insects $(96 \%)$ developed on $B$. pendula. About half of them were also observed on the East Asian birches $B$. dahurica, $B$. divaricata, $B$. costata, $B$. ermanii, and $B$. gmelinii; five species were found on the North American birches B. occidentalis and B. papyrifera. All the leaf mining species listed in our paper for Siberia also occur in Europe. The similarity between the miner faunas of these regions is discussed and it is warned about possible errors in diagnostics of the Siberian species using the keys and catalogues for the European fauna. The importance of DNA barcoding in the study of the local insect faunas of poorly explored regions is also emphasized.
\end{abstract}

DOI: $10.1134 / \mathrm{S} 0013873817020051$

In Russia, and in particular in Siberia, birch is one of the most widespread deciduous trees (Koropachinsky and Vstovskaya, 2012). The silver birch Betula pendula Roth is the commonest representative of the genus. This species is the pioneer of colonization of cleared or burnt-out places and waste lands; it forms grassy secondary forests improving the soil quality (Korchagina, 1980). Birches are often used in shelter belts and urban landscaping. Due to the beautiful light green foliage, white bark, and elegant crown, not only the local but also the introduced species of Betula are grown for ornamental purposes in parks and public gardens (Bakulin et al., 2008).

The genus Betula L. is represented by a hundred species and forms in the Russian botanical gardens. The largest collection of birch species is gathered in the Main Botanical Garden of the Russian Academy of
Sciences in Moscow. The collection of the Central Siberian Botanical Garden of the Siberian Branch of the Russian Academy of Sciences (CSBG, Novosibirsk) has over ten birch species and forms brought from various floristic regions (Vstovskaya and Koropachinsky, 2005).

Birches are damaged by many insect species (Belov, 2013). In Moscow parks and public gardens, birches serve as host plants for 163 species (Belov, 2013). In Siberia, it is estimated that about 400 arthropod species feed on birch (Barannik, 1981; Yanovsky, 2003). Among phyllophagous insects, leaf miners are regularly found on birch (Barannik, 1981; Tarasova and Sanina, 2004; Tarasova, 2005; Selikhovkin et al., 2012; Belov, 2013). This is an endophagous group of insects whose larvae live in mines in the leaf tissues (Hering, 1951). Leaf miners are known among repre- 
sentatives of the orders Lepidoptera, Hymenoptera, Coleoptera, and Diptera (Hering, 1951). Mass mining of leaves reduces the surface involved in photosynthesis and disrupts water balance, leading to slower growth, premature falling of leaves, and also decreases resistance to diseases (Proctor et al., 1982; Raimondo et al., 2003; Wagner et al., 2008).

In the recent years, this ecological group of insects has attracted much attention of researchers due to the rapid expansion of many species and the extensive damage to woody plants in parks, gardens, and forests (Lopez-Vaamonde et al., 2010; Selikhovkin et al., 2012; De Prins and De Prins, 2015; Edmunds, 2015; Ellis, 2015). Invasive species are especially numerous among leaf mining moths. During the last decades, the list of invaders was supplemented, in particular, by moths of the families Gracillariidae, Yponomeutidae, Gelechiidae, and others (Šefrová and Laštůvka, 2009; Lopez-Vaamonde et al., 2010). Many of them have colonized important forest and ornamental woody plant species.

In Siberia, the group of leaf mining insects remains poorly studied. For example, the Catalogue of the Lepidoptera of Russia (2008) contains little data on the taxonomic diversity and distribution of leaf mining moths in Siberia as compared to western and eastern regions of the country. Data on the distribution of leaf mining beetles, sawflies, and flies in Siberia are even scarcer.

The goal of this work was to study the taxonomic diversity and distribution of leaf mining insects on birches in Siberia, based on the literary data and our records. The trophic specialization of leaf mining insects was studied, pests and invasive species were listed, and comparative analysis of the faunas of insects mining birch leaves in Siberia and Europe was performed.

\section{MATERIALS AND METHODS}

The taxonomic diversity of insects mining birch leaves was studied in 2008-2015 in 12 administrative regions of Siberia (Fig. 1). In Novosibirsk Province and Krasnoyarsk Territory research was carried out yearly in May-September; in other regions, once or twice in June-July 2009-2015. Collections were made in parks, arboreta, and botanical gardens in the administrative centers of the regions (Fig. 1). In addition, we examined the natural forests around Krasnoyarsk and Novosibirsk, and also the forests in Kemerovo Province and Altai Republic (see notes to Fig. 1).
Overall, ten birch species were studied: the Eurasian silver birch $B$. pendula Roth and downy birch $B$. pubescens Ehrh., the Asian species B. microphylla Bunge, B. dahurica Pall., B. divaricata Ledeb., B. costata Trautv., B. ermanii Cham., and B. gmelinii Bunge, and the North American water birch $B$. occidentalis Hook. and the paper birch B. papyrifera Marsh. Betula gmelinii is a dubious species; it is regarded as a hybrid having common characters of B. humilis Schrank, B. fruticosa Pall., and B. ermanii (Koropachinsky and Vstovskaya, 2012, p. 199). All birch species listed above were surveyed in CSBG. In other regions, $B$. pendula was mainly studied. Altogether, about 2000 birch plants were examined, aged from 5 to 70 years and varying in height from 2.5 to $30 \mathrm{~m}$.

Birch leaves were examined for damage of leaf miners (i.e., for mines). Young birch trees (up to $3 \mathrm{~m}$ tall) were examined along the whole height, while in older trees only the lower part of the crown was examined. The leaves with mines were collected and preserved in a herbarium (Hering, 1951; Kirichenko, 2014); the mines and their inhabitants were photographed with a Sony Nex-3 digital camera. The insect larvae and pupae found in mines were placed in $96 \%$ ethanol to preserve their DNA (Doorenweerd and Beentjes, 2012). Collecting insects directly from mines allowed us to document their host plants. In some cases, adults were reared from the larvae under laboratory conditions (Hering, 1951; Kirichenko, 2014). The miners were identified using Russian and European keys (Hering, 1957; Key to the Insects..., 1978, 1997; Gusev, 1984; Insects and Acarines..., 1999; Gregor and Patočka, 2001; Ellis, 2015). Identification of moths of the families Nepticulidae and Gracillariidae as well as weevils of the family Curculionidae was checked by experts.

Larvae and pupae of 15 insect species were used for DNA barcoding, i.e., sequencing of the barcoding fragment of the mitochondrial cytochrome oxidase I (COI) gene. DNA barcoding is widely used for reliable identification of arthropods, including leaf mining insects (Mutanen et al., 2013). A great advantage of this approach is that it allows identifying species based on their preimaginal stages, which is difficult or impossible to do using morphological characters. Genetic analysis of insects was performed in the Forest zoology laboratory of the French National Institute for Agricultural Research (INRA, Orléans). Altogether, 15 insect species were analyzed. Extraction and purification of DNA was performed using the QIAGEN 


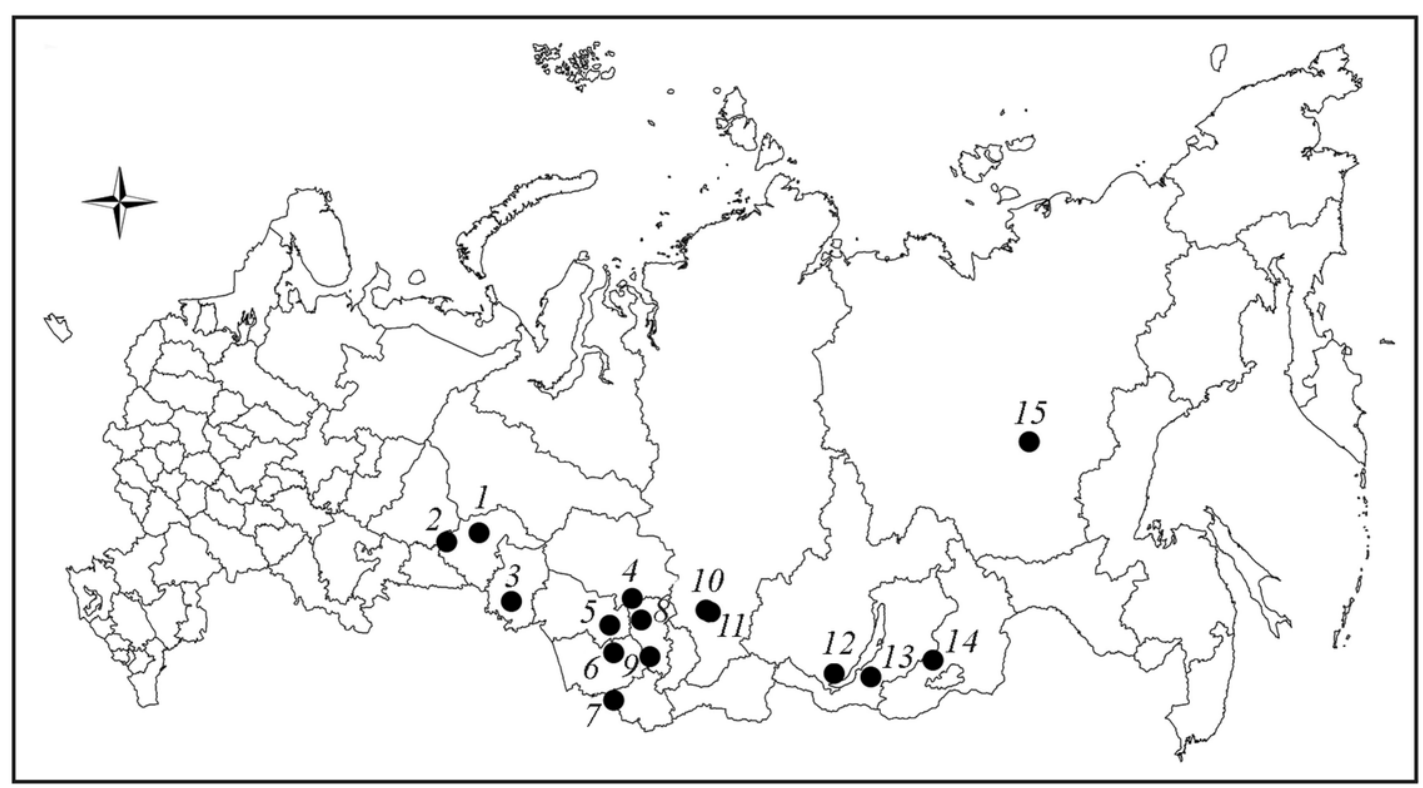

Fig. 1. The area of collection of birch leaf mining insects in Siberia in 2008-2015: (1, 2) Tyumen Province: (1) Tobolsk: Ermak Park, VI.2015; (2) Tyumen: Zatyumensky Park and adjoining forest zone, VI-VII.2013-2015; (3) Omsk Province, Omsk: Victory Park, VI-VII.2013-2015; (4) Tomsk Province, Tomsk: Siberian Botanical Garden of Tomsk State University, VI.2009; (5) Novosibirsk Province, Novosibirsk: CSBG and adjoining forest zone, VI-VIII.2008-2015; (6) Altai Territory, Barnaul: Izumrudny Park, VII.2015; (7) Altai Republic: Chike-Taman Pass, VII.2013; (8,9) Kemerovo Province: (8) Kemerovo: Antoshka Park, VII.2015; (9) Kuzedeevo: lime grove, VI.2013; $(10,11)$ Krasnoyarsk Territory: (10) Krasnoyarsk: Arboretum of SIF SB RAS and adjoining forest zone, VI-VIII.2008-2015; (11) Trostentsovo: suburban forest, VI-VIII.2011-2015; (12) Irkutsk Province, Irkutsk: botanical garden of Irkutsk State University, VIII.2015; (13) Buryatia Republic, Ulan-Ude: plantings in Zheleznodorozhny District, VIII.2015; (14) Transbaikalia, Chita: Victory Park, VIII.2015; (15) Sakha Republic (Yakutia), Yakutsk: environs of North-Eastern Federal University, VIII.2015.

DNeasy Blood \& Tissue Kit. The mitochondrial DNA fragment was amplified and sequenced using the primers LCO (5' GGT CAA CAA ATC ATA AAG ATA TTG G 3') and HCO (5' TAA ACT TCA GGG TGA CCA AAA AAT CA 3'), 658 bp long (Folmer et al., 1994). The conditions of amplification and sequencing were described in our earlier papers (Kirichenko et al., 2015, 2016). Samples of three insect species were sequenced in the Canadian Centre for DNA Barcoding (Biodiversity Institute of Ontario, University of Guelph) using the standard protocol (Ivanova et al., 2006). All sequences were edited in CodonCode Aligner V.3.7.1. and compared with references in the BOLD database (Ratnasingham and Hebert, 2007).

Data on the distribution of insects mining birch leaves in Siberia were extracted from the literature (Forest Pests, 1955; Ilyinsky, 1962; Tomilova, 1962, 1973; Tibatina and Stroganova, 1966; Tibatina, 1970; Dovnar-Zapolsky and Tomilova, 1978; Barannik, 1981; Gershenzon, 1981; Kuznetsov, 1981; Gusev, 1984; Yanovsky, 1996, 2003; Kuznetsov and Baryshnikova, 1998, 2003; Insects and Acarines..., 1999; Tarasova and Sanina, 2004; Tarasova et al., 2004; Krivets, 2007; Catalogue..., 2008; Legalov,
2010; Baryshnikova, 2014) and supplemented with our observations. The Latin names and trophic associations of species are given according to the modern databases (De Prins and De Prins, 2015; Edmunds, 2015; Ellis, 2015; Fauna Europaea, 2015). In our paper the leaf miners are divided into mono-, oligo-, and polyphagous according to the accepted classification (Hering, 1951; Ellis, 2015): monophagous insects damage plants of one genus; oligophagous, plants of one family or, less frequently, plants of related families of the same order; polyphagous, a wide range of plant species from unrelated families and orders. Data on the richness of leaf mining insects on birches in Europe were borrowed from Hering (1951) and Ellis (2015). The leaf mining species richness in Siberia and Europe was compared using the ChekanovskySørensen similarity index: $K_{\mathrm{S}}=2 C /(A+B)$, where $C$ is the number of species common to the lists compared, and $A$ and $B$ are the numbers of species in each list (Magurran, 2004). This index was calculated both for comparing the overall leaf miner richness (including representatives of all the four orders: Lepidoptera, Hymenoptera, Coleoptera, and Diptera), and for individual orders. 
Table 1. Leaf mining insects erroneously listed as birch consumers in the Russian literature ${ }^{1}$ and their actual host plants $^{2}$

\begin{tabular}{|c|c|c|c|}
\hline No. & Order, family, and species of insect & $\begin{array}{c}\text { Trophic } \\
\text { specialization }^{3}\end{array}$ & Family and genus of actual host plants \\
\hline \multicolumn{4}{|c|}{$\begin{array}{l}\text { Order LEPIDOPTERA } \\
\text { Family Coleophoridae }\end{array}$} \\
\hline 1 & Coleophora paripennella Zeller & $\mathrm{O}$ & $\begin{array}{l}\text { Asteraceae (Arctium, Arnica, Carduus, Carlina, } \\
\text { Centaurea, Cirsium, Saussurea, Serratula, Solidago) }\end{array}$ \\
\hline \multicolumn{4}{|c|}{ Family Gracillariidae } \\
\hline 2 & Caloptilia elongella (Linnaeus) & M & Betulaceae $($ Alnus $)$ \\
\hline \multicolumn{4}{|c|}{ Family Yponomeutidae } \\
\hline 3 & Swammerdamia pyrella (Villers) & $\mathrm{O}$ & Rosaceae (Crataegus, Malus, Prunus, Pyrus) \\
\hline \multicolumn{4}{|c|}{$\begin{array}{l}\text { Order COLEOPTERA } \\
\text { Family Curculionidae }\end{array}$} \\
\hline 4 & Orchestes alni (Linnaeus) & M & Ulmaceae (Ulmus) \\
\hline \multicolumn{4}{|c|}{$\begin{array}{l}\text { Order HYMENOPTERA } \\
\text { Family Tenthredinidae }\end{array}$} \\
\hline 5 & Heterarthrus fasciatus (Malaise) & M & Salicaceae (Populus) \\
\hline 6 & H. ochropoda (Klug) & M & Salicaceae (Populus) \\
\hline
\end{tabular}

${ }^{1}$ According to: Tibatina, 1970; Dovnar-Zapolsky and Tomilova, 1978; Gershenzon, 1981; Yanovsky, 2003. ${ }^{2}$ According to: Hering, 1951, 1957; Edmunds, 2015; Ellis, 2015; Fauna Europaea, 2015. ${ }^{3}$ Trophic specialization: M, monophagous; O, oligophagous.

\section{RESULTS AND DISCUSSION}

Taxonomic diversity of leaf mining insects on birches in Siberia. In the Russian literature published in 1955-2010, a total of 52 insect species were listed as leaf miners of birches in Siberia. However, this list has some inaccuracies. In the literature sources, three insect species were simultaneously listed under the valid name and a synonym: Eriocrania cicatricella (Zetterstedt) was mentioned in the same publication as E. cicatricella and E. rubroaurella (Haworth); Stigmella lapponica (Wocke) was mentioned as Nepticula lapponica Wocke and N. vossensis Gronlien; Swammerdamia caesiella (Hübner) was mentioned as S. caesiella and $S$. heroldella Hübner (DovnarZapolsky and Tomilova, 1978; Yanovsky, 2003). The micro-moth Parornix betulae (Stainton) was referred to as P. devoniella (Stainton) (Catalogue..., 2008), though in fact these are two different species (De Prins and De Prins, 2015; Ellis, 2015; Fauna Europaea, 2015). Birch was mistakenly mentioned as a host plant for 6 insect species, including 3 moths, 2 sawflies, and one beetle species (Table 1).

Taking into account the double names of some species and erroneous indication of host plants, the list of miner insects associated with birches in Siberia has been narrowed down to 44 species (Table 2).
Among insects mining birch leaves in Siberia, the order Lepidoptera has the highest taxonomic diversity, comprising 31 species $(71 \%$ of the whole number of birch leaf miners) from 15 genera and 8 families (Fig. 2). The family Gracillariidae is the most diverse, with 8 species from 3 genera (Caloptilia, Parornix, and Phyllonorycter); it is followed by the families Nepticulidae with 7 species from 2 genera (Ectoedemia, Stigmella) and Eriocraniidae with 6 species from 2 genera (Eriocrania and Heringocrania) (Fig. 2).

The remaining three orders, namely Coleoptera, Hymenoptera, and Diptera, are represented by one family each (Fig. 2). The 7 beetle species inhabiting birches in Siberia belong to 4 genera: Anoplus Germar, Orchestes Ill., Rhamphus Clairv., and Tachyerges Schoenh. The identity of the weevil Orchestes calceatus (Germar) remains a matter of debate. Some authors consider $O$. calceatus and its close relative $O$. testaceus (Müller) to be one species, based on the absence of clear morphological differences (Legalov, 2010); others distinguish these species by the body coloration and the rostrum morphology and indicate birch as a host plant for $O$. calceatus and alder for $O$. testaceus (Dedyukhin, 2012; Koštál and Caldara, 2013). Birch leaves are also mined by 5 sawfly species from 5 genera: Fenusa Leach, Fenusella Enslin, Heterarthrus Steph., Profenusa MacGillivray, and Sco- 


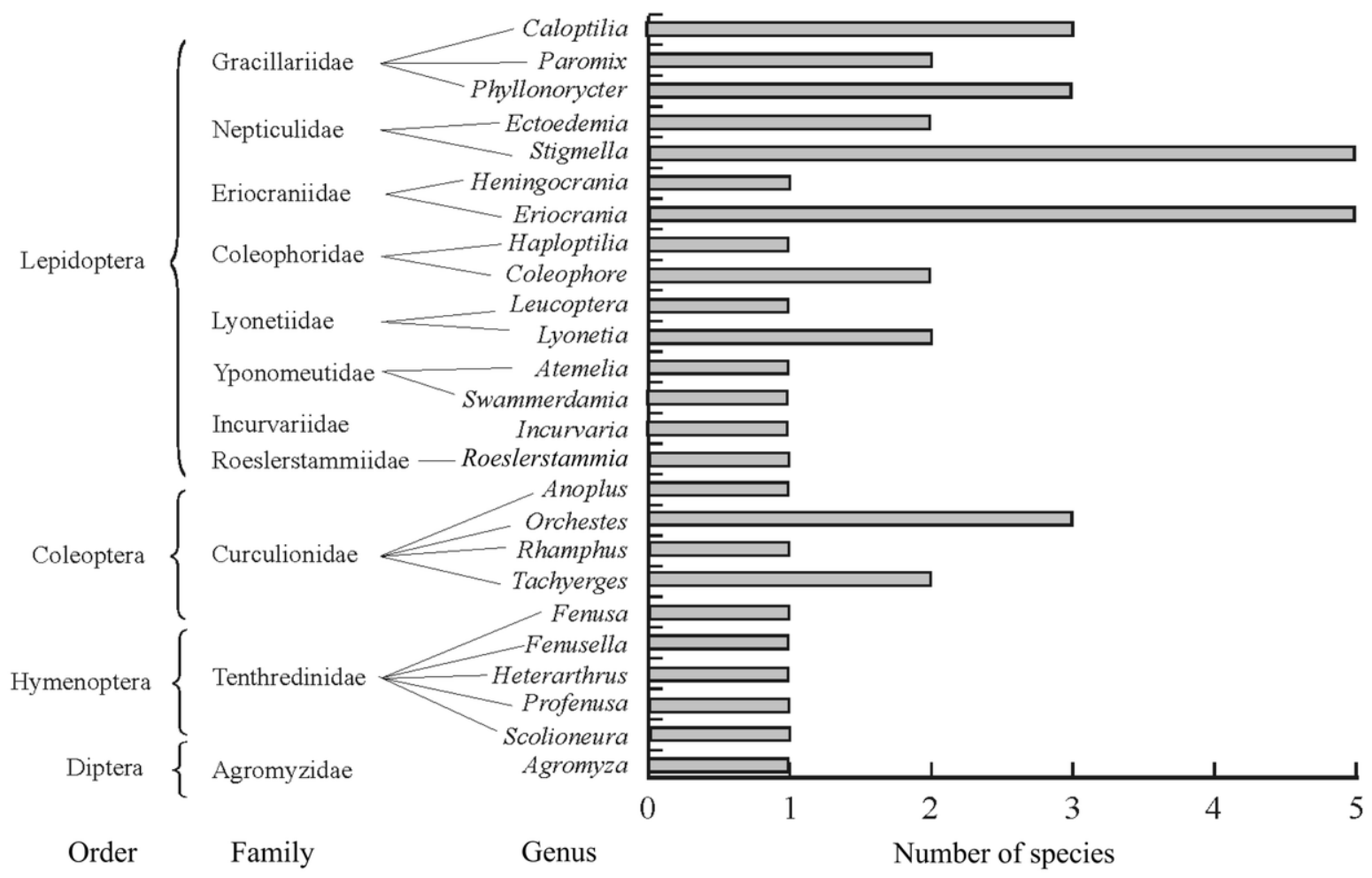

Fig. 2. Taxonomic diversity of leaf mining insects on birches in Siberia.

lioneura Konow (Fig. 2). Leaf mining flies are represented on birches in Siberia by a single species Agromyza alnibetulae.

Our collections included over 2500 mined leaves and 400 specimens of leaf mining larvae and pupae as well as adults reared from mines. In all, 25 leaf mining species were identified among this material, which makes up a little more than half the total number of leaf miners known on birches in Siberia according to the published data (Table 2). The species which we identified are marked with + in Table 2 ; the photographs of larvae and mines of most of these species, and also the cases of casebearer moths are shown in Fig. 3.

The larvae and pupae of 15 leaf mining species were identified using DNA barcoding. Their sequences were published in the BOLD database and can be accessed at dx.doi.org/10.5883/DS-BETULEAF. Thirteen species were identified with 99.2-100\% match. The BOLD database showed a considerable similarity of the Siberian sequences to those from Europe (Finland, Germany, France, Norway, the Netherlands, Austria, and Czech Republic). In many cases, sequences of the Siberian sawflies were found to be close not only to the European but also to the Cana- dian ones (Table 2), which could be expected keeping in mind the history of invasion of these insects into North America (see the section Pests and invasive species below). Two moth specimens from Siberia were identified as Heringocrania unimaculella and Lyonetia clerkella by their mitochondrial COI gene fragments with 97.46 and $98.02 \%$ match, respectively. Differentiation of the Lepidoptera species using DNA barcoding is most commonly based on a $2 \%$ threshold (Hebert et al., 2010; Rougerie et al., 2014). In our case, this threshold was slightly exceeded, which might indicate both a high level of genetic polymorphism in the geographic populations of these insects and the existence of potentially new species in Siberia. Additional studies are required to ascertain the status of these Siberian specimens.

Trophic specialization. Almost two-thirds of the insects mining birch leaves in Siberia are monophagous, developing only on Betula spp. (Table 2). About $5 \%$ of the leaf mining species are oligophagous and occur not only on birches but also on other representatives of the family Betulaceae, most often alder (Alnus). These are the micro-moths Incurvaria pectinea and Atemelia torquatella, the weevils Anoplus plantaris and Orchestes testaceus, and the sawfly 

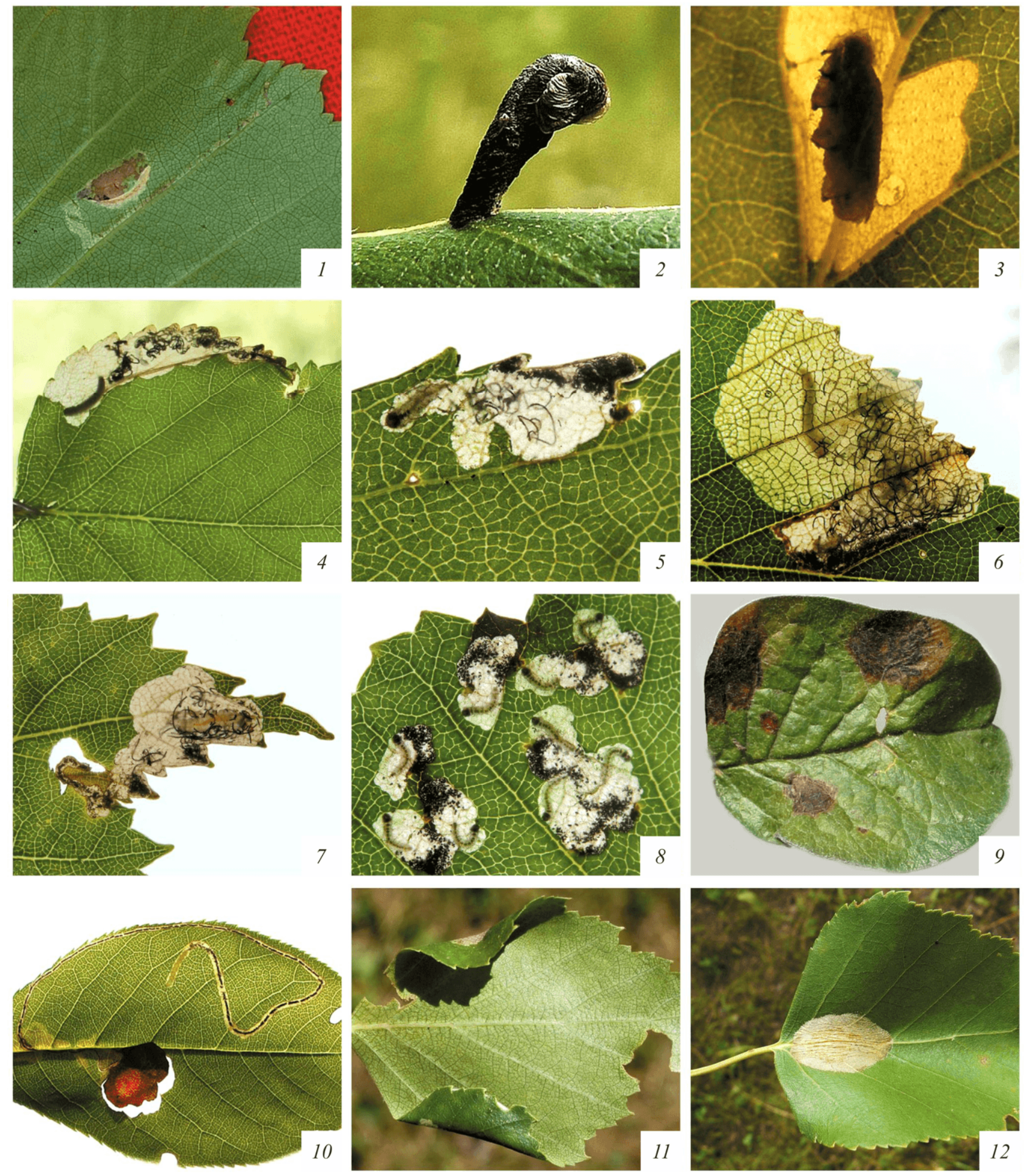

Fig. 3. Insect mines found on birch leaves in Siberia in 2008-2015. Lepidoptera: (1) Caloptilia betulicola on Betula pendula, Krasnoyarsk, Akademgorodok, Yenisei river bank, 19.VI.2013; (2) a case of Coleophora betulella on B. pendula, Novosibirsk, CSBG, 17.VI.2010; (3) a case of Haploptilia serratella on B. pendula, Krasnoyarsk, arboretum of Sukachev Institute of Forest (SIF), 31.V.2009; (4) Eriocrania sangii on B. pendula, Krasnoyarsk, Akademgorodok, Yenisei river bank, 13.VI.2013; (5) E. semipurpurella on B. pendula, same locality, 13.VI.2013; (6) E. sparmanella on B. pendula, Novosibirsk, CSBG, 17.VI.2010; (7) Heringocrania unimaculella (?) on B. pendula, Krasnoyarsk, Akademgorodok, Yenisei river bank, 19.VI.2013; (8) Incurvaria pectinea on B. pendula, same locality, 19.VI.2013; (9) Leucoptera malifoliella on Cotoneaster melanocarpus, Altai Republic, Chuisky highway, Chike-Taman Pass, 15.VII.2012; (10) Lyonetia clerkella (?) on Prunus padus, Novosibirsk, CSBG, 13.VI.2011; (11) Parornix betulae on B. costata, 

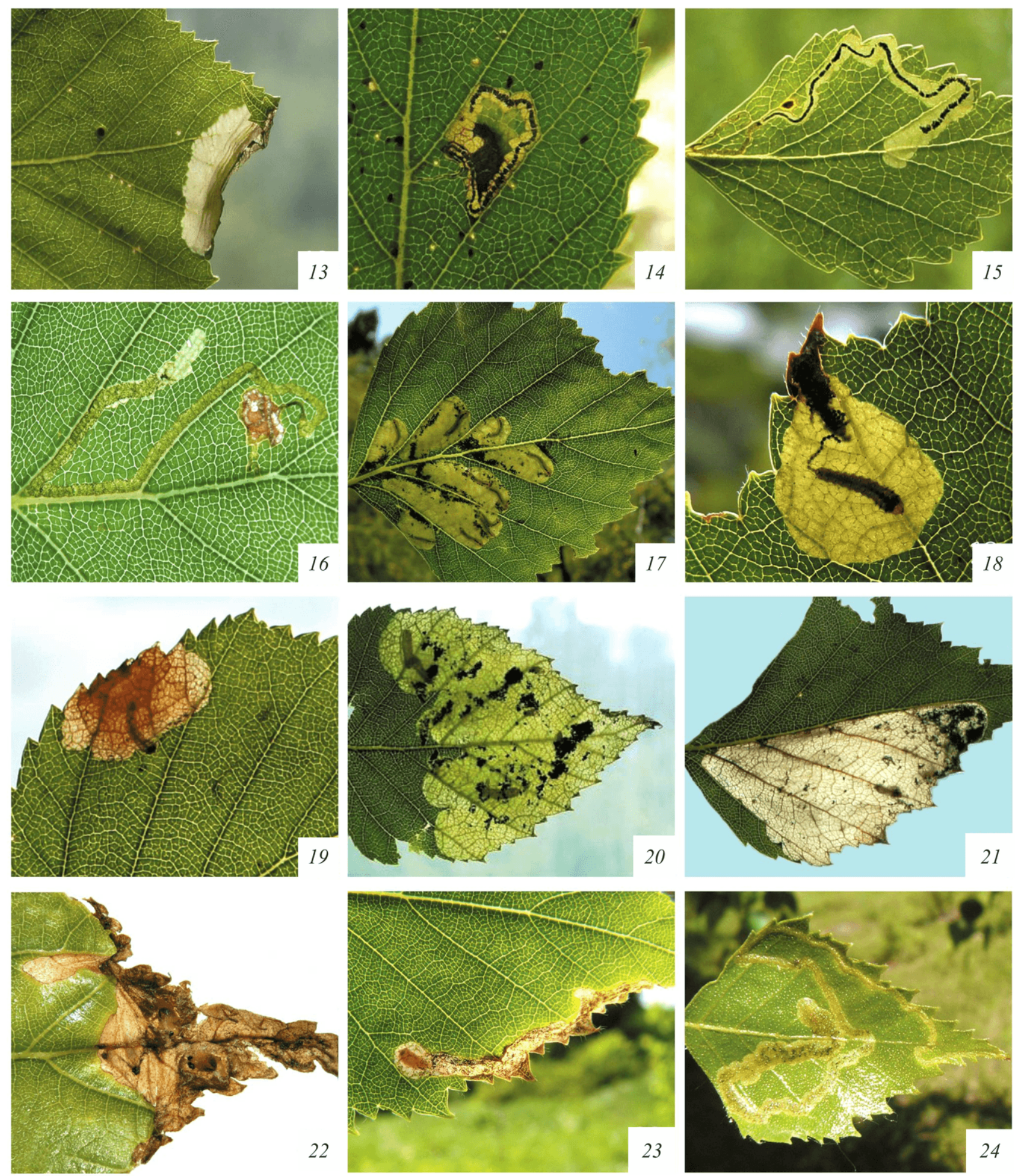

Novosibirsk, CSBG, 14.VI.2012; (12) Phyllonorycter corylifoliella on B. pendula, same locality, 10.VII.2010; (13) Ph. ulmifoliella on B. pendula, Krasnoyarsk, SIF arboretum, 10.VII.2011; (14) Stigmella betulicola on B. occidentalis, same locality, 7.VII.2009; (15) S. lapponica on B. microphylla, same locality, 12.VI.2011; (16) S. continuella on B. pendula, same locality, 11.VII.2012. Hymenoptera: (17) Fenusa pumila on B. pendula, Novosibirsk, CSBG, 17.VI.2010; (18) Fenusella nana on B. pendula, same locality, 12.VI.2009; (19) Heterarthrus nemoratus on B. pendula, Krasnoyarsk, Akademgorodok, Yenisei river bank, 11.VII.2011; (20) Profenusa thomsoni on B. pendula, same locality, 11.VII.2011; (21) Scolioneura betuleti on B. pendula, same locality, 11.VII.2011. Coleoptera: (22) Orchestes jota on B. pendula, Novosibirsk, CSBG, 11.VII.2012; (23) O. rusci on B. pendula, same locality, 16.VI.2010. Diptera: (24) Agromyza alnibetulae on B. pendula, same locality, 16.VI.2010. Photos by N.I. Kirichenko. 
Table 2. Birch leaf mining insects in Siberia: accuracy of DNA diagnostics and a list of their host plants ${ }^{1}$

\begin{tabular}{l|l|c|c|c}
\hline No. & Order, family, and species of insect & $\begin{array}{c}\text { Specimen ID and } \\
\text { accuracy of DNA } \\
\text { diagnostics }^{2}\end{array}$ & $\begin{array}{c}\text { Trophic } \\
\text { speciali- } \\
\text { zation }^{3}\end{array}$ & Host plants in Siberia \\
\hline
\end{tabular}

1 Coleophora anatipenella (Hübner, 1796)

2 C. betulella Heinemann et Wocke, $1876 \dagger$

3 Haploptilia serratella (Linnaeus, 1761) $\dagger$

Order LEPIDOPTERA

Family Coleophoridae

$4 \quad$ Eriocrania cicatricella (Zetterstedt, 1839) $\dagger$

5 E. salopiella (Stainton, 1854)

6 E. sangii (Wood, 1891) $\dagger$

7 E. semipurpurella Stephens, $1835 \dagger$

8 E. sparrmannella (Bosc, 1791) $\dagger$

9 Heringocrania unimaculella (Zetterstedt, $1839)^{\bullet} \dagger$

$10 \mid$ Caloptilia betulicola (Hering, 1928) $\dagger$

11 C. populetorum (Zeller, 1839)

12 C. suberinella (Tengström, 1848)

13 Parornix betulae (Stainton, 1854) $\dagger$

4 P. traugotti Svensson, 1976

15 Phyllonorycter cavella (Zeller, 1846)

16 Ph. corylifoliella (Hübner, 1796) $\dagger$

17 Ph. ulmifoliella (Hübner, 1817) $\dagger$

18 Incurvaria pectinea Haworth, $1828 \dagger$

$19 \mid$ Leucoptera malifoliella (O. Costa, 1836) $\dagger$

20 Lyonetia clerkella (Linnaeus, 1758) $\bullet$

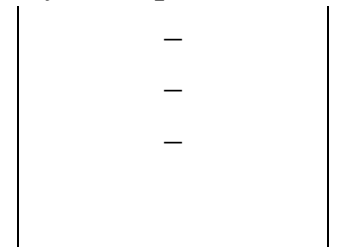

Family Eriocraniidae

-
-
SIBLE009-15
99.48\%; FI
-
SIBLE006-15
100\%; FI
SIBLE008-15
97.46\%; AT

Family Gracillariidae

GRAS002-13

$99.83 \%$; FI, NL

$$
-
$$

GRPAL1104-13

$100 \%$; DE, FI, NL

$$
-
$$

GRPAL1112-13

99.82\%; NL,

$\mathrm{DE}, \mathrm{CZ}$

GRPAL1127-13

$100 \%$; AT, DE,

FI, FR

Family Incurvariidae

SIBLE003-15

99.24\%; DE

Family Lyonetiidae

SIBLE001-15

99.83\%; FI

SIBLE004-15

98.02\%; NO
P $\quad$ Betula, many Rosaceae

M Betula,$[$ B. pendula $]$

P Betula, (Acer), [Betula dahurica*, B. divaricata* ${ }^{*}$. pendula, B. ermanii*]

\begin{tabular}{l|l}
$\mathrm{M}$ & Betula,$[$ B. pendula $]$ \\
$\mathrm{M}$ & Betula \\
$\mathrm{M}$ & Betula,$[$ B. pendula $]$ \\
$\mathrm{M}$ & Betula,$[$ B. pendula $]$ \\
$\mathrm{M}$ & Betula,$[$ B. dahurica*, B. pendula \\
$\mathrm{M}$ & B. microphylla, B. gmelinii* $]$ \\
& Betula,$[$ B. pendula $]$
\end{tabular}

M $\quad$ Betula, [B. pendula, B. pubescens]

M Betula, (Populus, Alnus)

M Betula

M Betula, [B. costata*, B. microphylla, B. occidentalis*, B. pendula]

M Betula pubescens

M Betula?

P Betula, [B. pendula, B. ermanii*], in Europe Rosaceae

M

Betula, [B. pendula $]$

P $\quad$ Alnus, Betula, Malus, Rhododendron, [Betula pendula]

P $\quad$ Betula, many Rosaceae [Cotoneaster melanocarpus, C. uniflorus, Crataegus sp., Betula pendula]

P Betula, Cotoneaster, Prunus, Malus [Prunus padus, P. virginiana, Cotoneaster melanocarpus] 
Table 2. (Contd.)

\begin{tabular}{|c|c|c|c|c|}
\hline No. & Order, family, and species of insect & $\begin{array}{l}\text { Specimen ID and } \\
\text { accuracy of DNA } \\
\text { diagnostics }^{2}\end{array}$ & $\begin{array}{l}\text { Trophic } \\
\text { speciali- } \\
\text { zation }^{3}\end{array}$ & Host plants in Siberia ${ }^{4}$ \\
\hline 21 & L. prunifoliella (Hübner, 1796) & - & $\mathrm{P}$ & Betula, Cotoneaster, Prunus \\
\hline \multicolumn{5}{|c|}{ Family Nepticulidae } \\
\hline 22 & Ectoedemia minimella (Zetterstedt, 1839) & - & M & Betula \\
\hline 23 & E. occultella (Linnaeus, 1767) & - & M & Betula \\
\hline 24 & Stigmella betulicola (Stainton, 1856) $\dagger$ & - & M & $\begin{array}{l}\text { Betula, }[\text { B. pendula, B. dahurica*, } \\
\left.\text { B. divaricata*, B. occidentalis }{ }^{*}\right]\end{array}$ \\
\hline 25 & S. confusella (Wood et Walsingham, 1894) & - & M & Betula \\
\hline 26 & S. lapponica (Wocke, 186262) $\dagger$ & - & M & $\begin{array}{l}\text { Betula, }[\text { B. pendula, B. dahurica*, } \\
\text { B. divaricata*] }\end{array}$ \\
\hline 27 & S. continuella (Stainton, 1862) $\dagger$ & - & M & [B. pendula $]$ \\
\hline 28 & S. luteella (Stainton, 1857) & - & M & Betula \\
\hline \multicolumn{5}{|c|}{ Family Roeslerstammiidae } \\
\hline 29 & Roeslerstammia erxlebella (Fabricius, 1787) & - & $\mathrm{P}$ & $\mid \begin{array}{l}\text { Betula, in Europe also Tilia, rarely } \\
\text { Acer }\end{array}$ \\
\hline \multicolumn{5}{|c|}{ Family Yponomeutidae } \\
\hline 30 & Atemelia torquatella (Lienig et Zeller, 1846) & - & $\mathrm{P}$ & Betula, Alnus, Ulmus \\
\hline 31 & Swammerdamia caesiella (Hübner, 1796) & - & M & Betula \\
\hline \multicolumn{5}{|c|}{$\begin{array}{l}\text { Order COLEOPTERA } \\
\text { Family Curculionidae }\end{array}$} \\
\hline 32 & Anoplus plantaris (Naezén, 1794) & - & $\mathrm{O}$ & $\begin{array}{l}\text { Betula, in other parts of Russia } \\
\text { also Alnus }\end{array}$ \\
\hline 33 & Orchestes jota (Fabricius, 1787) $\dagger$ & - & $\mathrm{P}$ & $\begin{array}{l}\text { Betula, Alnus, Myrica gale, (Salix, } \\
\text { Populus), [Betula microphylla, } \\
\left.\text { B. occidentalis }{ }^{*}, \text { B. pendula }\right]\end{array}$ \\
\hline 34 & O. rusci (Herbst, 1795) $\dagger$ & $\begin{array}{l}\text { ISSIK } 118-14 \\
99.85 \% ; \mathrm{FI}\end{array}$ & M & $\begin{array}{l}\text { Betula, }[\text { B. pendula, B. pubescens, } \\
\left.\text { B. microphylla, B. occidentalis }{ }^{*}\right]\end{array}$ \\
\hline 35 & O. calceatus (Germar, 1821) & - & $\mathrm{O}$ & Alnus, Betula \\
\hline 36 & Rhamphus pulicarius (Herbst, 1795) & - & $\mathrm{P}$ & Betula \\
\hline 37 & Tachyerges pseudostigma (Tempère, 1982) & - & $\mathrm{P}$ & Alnus, Betula, Corylus, Salix \\
\hline 38 & T. stigma (Germar, 1821) & - & $\mathrm{P}$ & Alnus, Betula, Salix, (Populus) \\
\hline \multicolumn{5}{|c|}{$\begin{array}{l}\text { Order HYMENOPTERA } \\
\text { Family Tenthredinidae }\end{array}$} \\
\hline 38 & Fenusa pumila Leach, $1817 \dagger$ & $\begin{array}{l}\text { ISSIK } 109-14 \\
99.54 \% ; \mathrm{NL}\end{array}$ & $\mathrm{O}$ & $\begin{array}{l}\text { Betula, Alnus, [Betula costata*, } \\
\text { B. dahurica*, B. gmelinii* } \\
\text { B. pendula }]\end{array}$ \\
\hline 40 & Fenusella nana (Klug, 1816) $†$ & $\begin{array}{l}\text { ISSIK } 135-14 \\
100 \% ; \text { CA, DE, } \\
\text { FI, NO }\end{array}$ & M & $\begin{array}{l}\text { Betula, }[\text { B. pendula, B. dahurica*, } \\
\text { B. microphylla, B. papyrifera } *]\end{array}$ \\
\hline 41 & Heterarthrus nemoratus (Fallén, 1808) † & $\begin{array}{c}\text { ISSIK } 119-14 \\
100 \% ; \text { CA, DE, NL }\end{array}$ & M & Betula,$[$ B. pendula $]$ \\
\hline 42 & Profenusa thomsoni (Konow, 1886) $\dagger$ & $\begin{array}{c}\text { ISSIK122-14 } \\
100 \% ; \text { CA, FI, FR }\end{array}$ & M & Betula, $[$ B. pendula $]$ \\
\hline
\end{tabular}


Table 2. (Contd.)

\begin{tabular}{c|c|c|c|c}
\hline No. & Order, family, and species of insect & $\begin{array}{c}\text { Specimen ID and } \\
\text { accuracy of DNA } \\
\text { diagnostics }\end{array}$ & $\begin{array}{c}\text { Trophic } \\
\text { speciali- }^{2}\end{array}$ & zation $^{3}$
\end{tabular}

Order DIPTERA

Family Agromyzidae

44 Agromyza alnibetulae Hendel, $1931 \dagger$

M |Betula, (Alnus), [Betula pendula, B. ermanii*]

${ }^{1}$ Based on the literature data (see Materials and Methods) and our records (in the latter case the species are marked with $\dagger$ ).

${ }^{2}$ This column contains identification number (ID) of Siberian samples in the BOLD database, the reliability (\%) of molecular diagnostics, and the origin of the reference specimens: AT, Austria; CA, Canada; CZ, Czech Republic; DE, Germany; FI, Finland; FR, France; NL, the Netherlands; NO, Norway. ${ }^{3}$ Trophic specialization: M, monophagous on Betula; O, oligophagous; P, polyphagous (see Materials and Methods). ${ }^{4}$ Host plants are listed based on the literature data (see Materials and Methods); doubtful indications of host plants in Russian literature (Forest Pests, 1955; Tomilova, 1962, 1972; Dovnar-Zapolsky and Tomilova, 1978; Barannik, 1981; Kuznetsov, 1981; Gusev, 1984; Yanovsky, 2003) which need to be verified are given in parentheses; our data are given in square brackets; * introduced plant species; ${ }^{\#}$ for notes on the identity of $O$. testaceus and $O$. calceatus, see Results and Discussion; ${ }^{\bullet}$ Additional studies are required to confirm the status of the Siberian specimens (see Results and Discussion).

Fenusa pumila (Table 2). About $30 \%$ of the leaf mining species are polyphagous; this group includes only micro-moths and beetles (Table 2). Besides birch and alder, they may feed on plants of the family Rosaceae and, less frequently, on Salicaceae and Ulmaceae.

For six insect species mining birch leaves in Siberia, the Russian publications listed some host plants which are not typical of these insects according to the modern databases (De Prins and De Prins, 2015; Edmunds, 2015; Ellis, 2015; Fauna Europaea, 2015). In particular, maple (Acer) was mentioned as a host plant for the casebearer Haploptilia serratella (Barannik, 1981), alder (Alnus) and poplar (Populus), for the moth Caloptilia populetorum (Tomilova, 1962, 1973; Kuznetsov, 1981), poplar and willow (Salix), for the weevils Orchestes jota and Tachyerges stigma (Yanovsky, 2003), poplar for the sawfly Scolioneura betuleti (Tomilova, 1962), and, finally, alder for the leafminer fly Agromyza alnibetulae (Forest Pests, 1955; Dovnar-Zapolsky and Tomilova, 1978; Gusev, 1984). The ability of these insects to develop on the indicated host plants needs to be confirmed.

In our survey, 23 out of 25 species of leaf mining insects were recorded on $B$. pendula and one, on B. pubescens (Table 2). About half of these species were also found on the introduced birches, mostly on the Eastern Asian species B. costata, B. dahurica, $B$. divaricata, B. ermanii, and B. gmelinii (Table 2). Five species (the micro-moths Parornix betulae and Stigmella betulicola, the beetles Orchestes jota and
O. rusci, and the sawfly Fenusella nana) occurred on the North American birches B. occidentalis and B. papyrifera (Table 2).

The apple leaf miner Lyonetia clerkella is a polyphagous species occasionally feeding on birch. We recorded this moth in Siberia on different plants of the family Rosaceae but never on birch (Table 2). Another polyphagous species, the pear leaf blister moth Leucoptera malifoliella, usually occurs on Rosaceae in Siberia. In August 2015, we found numerous mines of this species on leaves of young birches in Yakutsk.

Pests and invasive species. Nine insect species were listed in the literature as birch pests in the Palaearctic. This group includes 5 species of leaf mining micro-moths: Caloptilia betulicola, C. populetorum, C. suberinella, Coleophora serratella, and Phyllonorycter ulmifoliella (Barannik, 1981; Key to the Insects..., 1981) and 4 species of sawflies: Fenusa pumila, Fenusella nana, Heterarthrus nemoratus, and Profenusa thomsoni (Forest Pests, 1955; Tibatina and Stroganova, 1966; Stroganova, 1973). The sawfly $H$. nemoratus damages young birches in nurseries and shelter belts in Europe and European Russia (Forest Pests, 1955).

The four remaining species of polyphagous micromoths, namely Coleophora anatipenella, Leucoptera malifoliella, Lyonetia clerkella, and Phyllonorycter corylifoliella, cause considerable harm not to birches (although they can develop on them) but to trees of the family Rosaceae in gardens and parks; they are pests 
of apple, pear, hawthorn, rowan, plum, cherry, and other plants (Forest Pests, 1955; Tomilova, 1973; Insects and Acarines..., 1999). No pests are known among the leaf mining beetles and flies occurring on birches.

At the beginning of the XX century the leaf mining sawflies Fenusa pumila, Fenusella nana, Heterarthrus nemoratus, and Profenusa thomsoni, whose native ranges lie in the Palaearctic (including Siberia), invaded North America (Digweed et al., 2009). There they considerably damage the North American birch species, especially B. papyrifera. There are no invasive species among representatives of the orders Lepidoptera, Coleoptera, and Diptera occurring on birches in Siberia.

Distribution in Siberia. The distribution of leaf mining insects on birches in Siberia remains poorly known. In this respect, Novosibirsk and Irkutsk Provinces, where over a half of the known birch leaf miners have been recorded (Table 3), are the best explored regions of Siberia.

Our surveys provided new data about the distribution of leaf mining insects trophically associated with birches in Siberia. New distribution records were made for 20 species in Siberia (Table 3). Most of these species were for the first time recorded in Krasnoyarsk Territory (Krasnoyarsk) and Novosibirsk Province (Novosibirsk), which could be expected since material was collected repeatedly in these regions. For instance, some species of leaf mining micro-moths of the families Gracillariidae, Eriocraniidae, and Incurvariidae, and also sawflies earlier known from other Siberian regions were recorded in Krasnoyarsk for the first time. Some species of the genus Stigmella were for the first time found in several regions, and one of them, S. continuella, was discovered in Siberia for the first time (Fig. 3, 16). In Russia, this micro-moth species had been earlier known only from the European part and from Primorskii Territory (Catalogue..., 2008). We recorded $S$. continuella in Western Siberia (Novosibirsk Province: Novosibirsk, CSBG, Betula pendula, mines with larvae, 11.VI.2012, coll. N.I. Kirichenko, det. E. van Nieukerken, 3 specimens). The following leaf mining insect species were for the first time recorded in three regions: Phyllonorycter corylifoliella in Omsk and Novosibirsk Provinces and Krasnoyarsk Territory; Stigmella lapponica in Tomsk and Kemerovo Provinces and the Buryatia Republic; Agromyza alnibetulae in Tomsk Province and in Altai and Krasnoyarsk Territories (Table 3). The pear leaf blister moth Leucoptera malifoliella was for the first time recorded in the Altai and Sakha (Yakutia) Republics (Table 3).

Findings of leaf mining insect species in new regions do not necessarily indicate an extension of their ranges but rather reflect insufficient knowledge of these insects in Siberia.

Richness of birch leaf miners in Siberia and Europe. The fauna of insects mining birch leaves in Siberia is surprisingly similar to that of Europe, as indicated by the relatively high value of the Chekanovsky-Sørensen index (0.77). The group of birch leaf miners includes 44 species in Siberia (Tables 2, 3) and 70 species in Europe (Hering, 1951; Ellis, 2015). All the species listed herein for Siberia can also be found on birches in Europe (Hering, 1951; De Prins and De Prins, 2015; Ellis, 2015). Comparison of the birch leaf miner faunas of Siberia and Europe yields the following values of the Chekanovsky-Sørensen index: $0.68,0.91,0.93$, and 1 for Lepidoptera, Hymenoptera, Coleoptera, and Diptera, respectively. The number of leaf mining beetles and sawflies is one species greater in Europe than in Siberia. The polyphagous jewel beetle Trachys minutus (Linnaeus) can be found on Betula in Europe, although in Siberia it develops on other woody plants but not on birches. The leaf mining sawfly Scolioneura vicina Konow feeds on birches in Europe but has never been recorded in Siberia. It is noteworthy that both regions are inhabited by the closely related species $S$. betuleti, which is, however, indistinguishable from S. vicina according to the recent molecular genetic research (Leppänen et al., 2012).

The difference between the faunas of Siberia and Europe is mainly due to leaf mining micro-moths. There are 10 species of Coleophoridae, 4 species of Nepticulidae, 3 species of Gracillariidae, and 1 species of Yponomeutidae that occur on birches in Europe but have never been recorded in Siberia (Hering, 1951; De Prins and De Prins, 2015; Ellis, 2015). Leaf mining micro-moths of the families Heliozelidae and Bucculatricidae were recorded on birches only in Europe (Ellis, 2015).

The Ural Mountains separating the European and the Asian parts of Russia do not seem to be an obstacle for dispersal of leaf miners and mixing of the regional faunas. However, this suggestion should be treated with some caution. Since the leaf mining insects of 
Table 3. Distribution of insect species mining birch leaves in the regions of Siberia*

\begin{tabular}{|c|c|c|c|c|c|c|c|c|c|c|c|c|c|c|c|}
\hline \multirow{2}{*}{ No. } & \multirow{2}{*}{ Insect species } & \multicolumn{14}{|c|}{ Regions of Siberia } \\
\hline & & 1 & 2 & 3 & 4 & 5 & 6 & 7 & 8 & 9 & 10 & 11 & 12 & 13 & 14 \\
\hline \multirow{2}{*}{\multicolumn{16}{|c|}{$\begin{array}{l}\text { Order LEPIDOPTERA } \\
\text { Family Coleophoridae }\end{array}$}} \\
\hline & & & & & & & & & & & & & & & \\
\hline 1 & Coleophora anatipenella & & & & & & + & & & & & + & & & \\
\hline 2 & C. betulella $\dagger$ & & & & $x$ & & & & & & & & & & \\
\hline 3 & Haploptilia serratella $\dagger$ & + & & & + & & & + & ○ & & & + & & & \\
\hline \multicolumn{16}{|c|}{ Family Eriocraniidae } \\
\hline 4 & Eriocrania cicatricella $\dagger$ & + & + & & + & + & & & ० & & & + & & & \\
\hline 5 & E. salopiella & & & & & & & & & & & $?$ & & & \\
\hline 6 & E. sangii $\dagger$ & + & + & & + & + & & & ○ & & & $?$ & & & \\
\hline 7 & E. semipurpurella $†$ & + & + & + & + & + & & & ○ & & & + & & + & + \\
\hline 8 & E. sparrmannella $\dagger$ & + & + & + & ○ & + & & & & & & + & & + & \\
\hline 9 & Heringocrania unimaculella $\dagger$ & + & + & & $x$ & + & & & & & & & & & \\
\hline
\end{tabular}

Family Gracillariidae

\begin{tabular}{l|l}
10 & Caloptilia betulicola $\dagger$ \\
11 & C. populetorum \\
12 & C. suberinella \\
13 & Parornix betulae $\dagger^{\bullet}$ \\
14 & P. traugotti \\
15 & Phyllonorycter cavella ${ }^{\#}$ \\
16 & Ph. corylifoliella $\dagger$ \\
17 & Ph. ulmifoliella $\dagger$
\end{tabular}

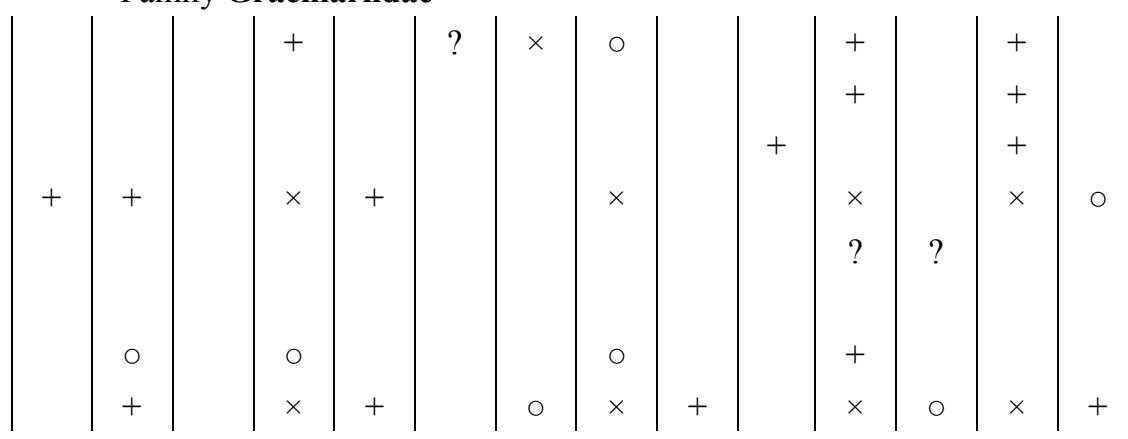

$18 \quad$ Incurvaria pectinea $\dagger$

Family Incurvariidae

\section{Family Lyonetiidae}

\begin{tabular}{l|l}
19 & Leucoptera malifoliella $\dagger$ \\
20 & Lyonetia clerkella $\dagger$ \\
21 & L. prunifoliella
\end{tabular}

22 Ectoedemia minimella

23 E. occultella

24 Stigmella betulicola $\dagger$

25 S. confusella

26 S. lapponica $\dagger$

27 S. continuella $\dagger$

28 S. luteella

29 Roeslerstammia erxlebella
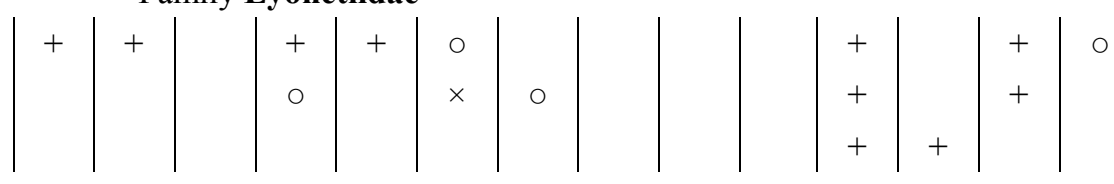

Family Nepticulidae
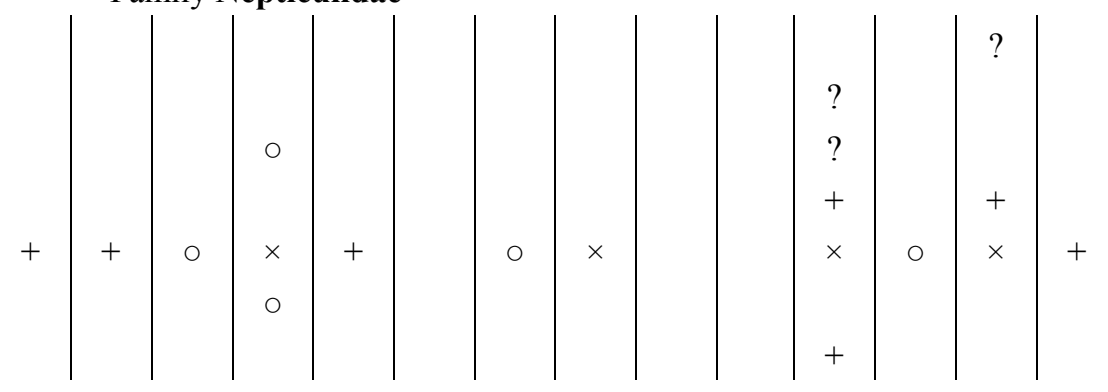

Family Roeslerstammiidae

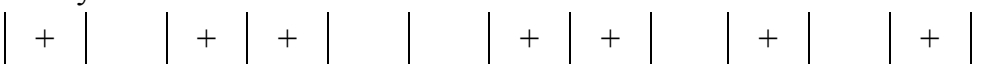

Family Yponomeutidae

\begin{tabular}{l|l}
30 & Atemelia torquatella \\
31 & Swammerdamia caesiella \\
\hline
\end{tabular}

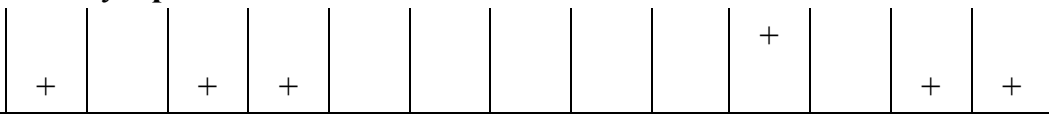


Table 3. (Contd.)

\begin{tabular}{|c|c|c|c|c|c|c|c|c|c|c|c|c|c|c|c|}
\hline \multirow{2}{*}{ No. } & \multirow{2}{*}{ Insect species } & \multicolumn{14}{|c|}{ Regions of Siberia } \\
\hline & & 1 & 2 & 3 & 4 & 5 & 6 & 7 & 8 & 9 & 10 & 11 & 12 & 13 & 14 \\
\hline \multicolumn{16}{|c|}{ Order COLEOPTERA } \\
\hline \multicolumn{16}{|c|}{ Family Curculionidae } \\
\hline 32 & Anoplus plantaris & & & & + & & & + & + & & & + & & & \\
\hline 33 & Orchestes jota $\dagger$ & & & + & $x$ & $\times$ & & + & & & & + & & + & + \\
\hline 34 & O. rusci $\dagger$ & + & & + & $x$ & + & + & $x$ & $x$ & & & + & & + & + \\
\hline 35 & O. calceatus & + & + & + & + & + & + & + & ० & & + & + & + & + & + \\
\hline 36 & Rhamphus pulicarius & & & & + & & & & & & + & + & + & + & + \\
\hline 37 & Tachyerges pseudostigma & & & + & + & & & + & & & & + & + & + & \\
\hline 38 & T. stigma & & & & & & + & & + & & + & + & & & \\
\hline \multirow{2}{*}{\multicolumn{16}{|c|}{$\begin{array}{l}\text { Order HYMENOPTERA } \\
\text { Family Tenthredinidae }\end{array}$}} \\
\hline & & & & & & & & & & & & & & & \\
\hline 38 & Fenusa pumila $\dagger$ & & & & $x$ & & & + & & & & + & & & \\
\hline 40 & Fenusella nana $\dagger$ & & $\circ$ & & + & & & & ० & & & $\times$ & & & \\
\hline 41 & Heterarthrus nemoratus $\dagger$ & & & & + & & & + & ○ & & & $\times$ & & & \\
\hline 42 & Profenusa thomsoni $\uparrow$ & & & & & & & & ○ & & & + & & + & \\
\hline 43 & Scolioneura betuleti $\dagger$ & & & & $x$ & & + & & $x$ & & & + & & & \\
\hline \multirow{2}{*}{\multicolumn{16}{|c|}{$\begin{array}{c}\text { Order DIPTERA } \\
\text { Family Agromyzidae }\end{array}$}} \\
\hline & & & & & & & & & & & & & & & \\
\hline 44 & Agromyza alnibetulae $\dagger$ & & & $\circ$ & $x$ & & ○ & & ○ & & & $x$ & & & \\
\hline
\end{tabular}

* Based on the literature data (see Materials and Methods) and our records (in the latter case the species are marked with $\dagger$ ). Regions of Siberia: 1, Tyumen Province; 2, Omsk Province; 3, Tomsk Province; 4, Novosibirsk Province; 5, Altai Territory; 6, Altai Republic; 7, Kemerovo Province; 8, Krasnoyarsk Territory (south); 9, Republic of Khakassia; 10, Republic of Tuva; 11, Irkutsk Province; 12, Republic of Buryatia; 13, Transbaikalia; 14, Sakha Republic (Yakutia). + regions for which the presence of species is recorded in the literature (see references in Materials and Methods); $\times$ regions for which the presence of species was confirmed by our data corresponding to the records in the literature; $\circ$ regions indicated for the first time based on our records; ? (question mark) presence of the species in the region needs to be verified (Catalogue of the Lepidoptera of Russia, 2008); ${ }^{\bullet}$ the species is listed under the name Parornix devoniella (Stainton) in the Catalogue... (2008); ${ }^{\#}$ Phyllonorycter cavella was recorded in Siberia without indication of regions (Kuznetsov and Baryshnikova, 1998).

Siberia are commonly identified using the keys for Europe and European Russia, some diagnostics errors may occur. New and still undescribed Siberian leaf mining species may be quite similar to the European ones, differing only in small, barely discernible morphological details, so that such species can be quite easily confused with European ones when identified with European keys. A good example is our recent finding of the leaf mining micro-moth from the genus Micrurapteryx (Gracillariidae) on the peashrub Caragana arborescens Lam. in Siberia. For decades, this insect has been confused with $M$. gradatella (HerrichSchäffer, 1855) in the Russian literature (DovnarZapolsky and Tomilova, 1978; Kuznetsov and Baryshnikova, 1998; Insects and Acarines..., 1999). However, the latter is distributed in Europe on some other legumes. Based on DNA barcoding of the Siberian specimens and subsequent examination of the adult genitalia, we differentiated the two species and redescribed the Siberian species as $M$. caraganella (Hering, 1957) (Kirichenko et al., 2016).

Careful revision of the leaf mining insect fauna in Siberia with the use of not only morphological but also modern molecular genetic tools would allow the researchers to reliably assess the taxonomic richness of this group in Siberia and to reveal new leaf miner species which for a long time remained undiscovered or confused with European species. Development of DNA barcoding library of leaf mining insects of Siberia (Kirichenko et al., 2014) would increase the efficiency and reliability of their identification in this poorly studied region of the Palaearctic. 


\section{CONCLUSIONS}

Analysis of the Russian literature and our data allowed us to revise the list of birch leaf miners, to study their distribution, and also to clarify their trophic relations with the native and introduced Betula species in Siberia. Altogether, 44 leaf mining insect species were recorded on birches in Siberia. Two-thirds of them are micro-moths; some of them are known as pests of Betula and cultivated Rosaceae in the Palaearctic. Four out of five sawfly species damage birches not only in the Palaearctic but also in North America where they invaded several decades ago.

As the result of our study, new distribution records were made for 20 leaf mining species; besides, the micro-moth Stigmella continuella (Stainton, 1856) from the family Nepticulidae, previously known only from the extreme western and eastern regions of Russia, was found for the first time in Central Siberia. The majority of leaf-mining insect species from Siberia was identified using DNA barcoding. The efficiency and accuracy of this modern molecular genetic approach and its applicability to diagnostics of insects by larvae and pupae offer new source of data to researchers. This method will significantly improve our knowledge not only about taxonomic diversity, distribution, and trophic relations of leaf mining insects but also about their phylogeny and phylogeography.

\section{ACKNOWLEDGMENTS}

We are grateful to M.A. Tomoshevich and E.V. Banaeva (Novosibirsk) for help in organizing regular research in the Central Siberian Botanical Garden, to E.A. Akulov and V.V. Shishov (Krasnoyarsk) for collecting some specimens in Krasnoyarsk and Yakutsk, to S.A. Krivets (Tomsk) and B.A. Korotyaev (St. Petersburg) for confirming the identification of Curculionidae, to E. van Nieukerken and C. Doorenweerd (the Netherlands) for identification of Nepticulidae, to P. Triberti (Italy) for identification of Gracillariidae, to A. Roques (France) and the colleagues from the University of Guelph (Canada) for the possibility of performing DNA barcoding of insects. We also thank I.A. Mikhailova (Krasnoyarsk) for designing the map, Yu.N. Baranchikov (Krasnoyarsk) for fruitful discussion, and the anonymous reviewer for valuable comments which helped us to improve the manuscript.

The DNA barcoding was partly supported by the Canadian government via the Genome Canada program and Ontario Genomics Institute within the Inter- national Barcode of Life project, and also by the Natural Sciences and Engineering Research Council of Canada. Research in Siberia was supported by the Russian Foundation for Basic Research (grant 15-2902645 ofi-m) and by LE STUDIUM ${ }^{\circledR}$ regional foundation (grant INRA-URZF-007).

\section{REFERENCES}

1. Bakulin, V.T., Banaev, E.V., Vstovskaya, T.N., Kiseleva, T.I., Koropachinsky, I.Yu., Lapteva, N.P., Loskutov, R.I., Lyakh, E.N., Potemkin, O.N., and Chindyaeva, L.N., Woody Plants Used for Landscaping in Novosibirsk (Siberian Branch of Russian Academy of Sciences, Novosibirsk, 2008) [in Russian].

2. Barannik, A.P., Insects of Green Plantings in Industrial Cities of Kemerovo Province (Kemerovo State University, Kemerovo, 1981) [in Russian].

3. Baryshnikova, S., "Recent Faunistic and Taxonomic Studies of Mining Moths from the Bucculatricidae and Gracillariidae Families (Lepidoptera) in Russia," in Selected Abstracts and Papers of the First Baltic International Conference on Field Entomology and Faunistics, Ed. by J.R. Stonis, S.R. Hill, A. Diškus, and T. Auškalnis (Edukologija Publishers, Vilnius, 2014), pp. 23-29.

4. Belov, D.A., "The Role of Dendrophilous Arthropods in Urban Ecosystems," Lesnoi Vestnik 6 (98), 31-39 (2013).

5. Catalogue of the Lepidoptera of Russia, Ed. by S.Yu. Sinev (KMK Scientific Press, Moscow, 2008) [in Russian].

6. De Prins, J. and De Prins, W., Global Taxonomic Database of Gracillariidae (Lepidoptera) (2015). http:// www.gracillariidae.net (accessed 15.10.2015).

7. Dedyukhin, S.V., Weevils (Coleoptera, Curculionoidea) of Vyatka-Kama Interfluve: Fauna, Distribution, Ecology: A Monograph (Udmurt University, Izhevsk, 2012) [in Russian].

8. Digweed, S.C., MacQuarrie, C.J.K., Langor, D.W., Williams, D.J.M., Spence, J.R., Nystrom, K.L., and Morneau, L., "Current Status of Invasive Alien BirchLeafmining Sawflies (Hymenoptera: Tenthredinidae) in Canada, with Keys to Species," The Canadian Entomologist 141 (3), 201-235 (2009).

9. Doorenweerd, C. and Beentjes, K., Extensive Guidelines for Preserving Specimen or Tissue for Later DNA Work (Naturalis, The Netherlands, 2012). http://science.naturalis.nl/media/323024/preservingdna.pdf.

10. Dovnar-Zapolsky, D.P. and Tomilova, V.N., "Mining Insects of Siberia and Adjoining Territories," in Insects of East Siberia (Irkutsk State University, Irkutsk, 1978), pp. 20-51 [in Russian].

11. Edmunds, R., British Leafminers (2015). http://www. leafmines.co.uk/index.htm (accessed 15.10.2015).

12. Ellis, W.N., Bladmineerders van Europa (Leafminers of Europe) (2015). http://www.bladmineerders.nl/index. htm (accessed 1.10.2015). 
13. Fauna Europaea (2015). http://www.faunaeur.org/ (accessed 1.10.2015).

14. Folmer, O., Black, M., Hoeh, W., Lutz, R., and Vrijenhoek, R., "DNA Primers for Amplification of Mitochondrial Cytochrome C Oxidase Subunit I from Diverse Metazoan Invertebrates," Molecular Marine Biology and Biotechnology 3, 294-299 (1998).

15. Forest Pests, Ed. by A.A. Stackelberg (USSR Academy of Sciences, Moscow, 1955) [in Russian].

16. Gershenzon, Z.S., "Family Yponomeutidae: Ermine Moths," in Key to Insects of the European Part of the USSR. Lepidoptera, Vol. 4 (2), Ed. by G.S. Medvedev (Nauka, Leningrad, 1981), pp. 331-347 [in Russian].

17. Gregor, F. and Patočka, J., "Die Puppen der mitteleuropaischen Lithocolletinae," Mitteilungen des Internationalen Entomologischen Vereins Supplement 8, 1-186 (2001).

18. Gusev, V.I., Key to Injuries to Forest, Ornamental, and Fruit Trees and Shrubs (Lesnaya Promyshlennost, Moscow, 1984) [in Russian].

19. Hebert, P.D.N., DeWaard, J.R., and Landry, J.F., "DNA Barcodes for 1/1000 of the Animal Kingdom," Biology Letters 6, 359-362 (2010).

20. Hering, E.M., Bestimmungstabellen der Blattminen von Europa: einschliesslich des Mittelmeerbeckens und der Kanarischen Inseln. Band V, 1-3 (Dr. W. Junk, Gravenhage, 1957).

21. Hering, M.E., Biology of the Leaf Miners (W. Junk, Gravenhage, 1951).

22. Ilyinsky, A.I., Keys to Forest Pests (Selkhozizdat, Moscow, 1962) [in Russian].

23. Insects and Acarines Damaging Agricultural Crops, Vol. 3: Lepidoptera, Ed. by V.I. Kuznetsov (Nauka, St. Petersburg, 1999).

24. Ivanova, N.V., Dewaard, J.R., and Hebert, P.D.N., "An Inexpensive, Automation-Friendly Protocol for Recovering High-Quality DNA," Molecular Ecology Notes 6, 998-1002 (2006).

25. Key to Insects of the European Part of the USSR. Lepidopterans, Vol. 4 (1-2), Ed. by G.S. Medvedev (Nauka, Leningrad, 1978) [in Russian].

26. Key to Insects of the Russian Far East, Vol. 5, Part 1: Trichoptera and Lepidoptera, Ed. by P.A. Lehr (Dalnauka, Vladivostok, 1997) [in Russian].

27. Kirichenko, N.I., "Methodological Approaches to the Study of Insects Mining Leaves of Woody Plants," Izvestiya Sankt-Peterburgskoi Lesotekhnicheskoi Akademii 207, 235-246 (2014).

28. Kirichenko, N.I., Augustin, S., Roques, A., van Nieukerken, E.J., Doorenweerd, C., and Lopez-Vaamonde, C., "Development of DNA Barcoding Reference Library for Fast and Accurate Identification of Immature Stages of Potential Forest Insect Pests. North Asian Leafminers as an Example," in Proceedings of the All-Russian Conference "Forest Ecosystems of the Boreal Zone: Geography, Structure, Function and Dynamics" (Krasnoyarsk, 2014), pp. 632-634.
29. Kirichenko, N., Huemer, P., Deutsch, H., Triberti, P., Rougerie, R., and Lopez-Vaamonde, C., "Integrative Taxonomy Reveals a New Species of Callisto (Lepidoptera, Gracillariidae) in the Alps," ZooKeys 473, 157-179 (2015).

30. Kirichenko, N., Triberti, P., Mutanen, M., Magnoux, E., Landry, J.-F., and Lopez-Vaamonde, C., "Systematics and Biology of Some Species of Micrurapteryx Spuler (Lepidoptera, Gracillariidae) from the Holarctic Region, with Re-Description of $M$. caraganella (Hering) from Siberia," ZooKeys 579, 99-156 (2016).

31. Korchagina, I.A., "Family Betulaceae," in The Life of Plants. Flowering Plants, Vol. 5, Part 1, Ed. by A.L. Takhtajan (Prosveshchenie, Moscow, 1980), pp. 311-324 [in Russian].

32. Koropachinsky, I.Yu. and Vstovskaya, T.N., Woody Plants of Asian Russia (Siberian Branch of Russian Academy of Sciences, Novosibirsk, 2012) [in Russian].

33. Koštál, M. and Caldara, R., "Taxonomic and Nomenclatural Notes on Orchestes testaceus (Müller) and O. calceatus (Germar) (Coleoptera: Curculionidae: Curculioninae)," Koleopterologische Rundschau. Wien 83, 185-191 (2013).

34. Krivets, S.A., "Review of Weevils (Coleoptera: Brentidae, Dryophthoridae et Curculionidae) of Tomsk Province," Trudy Russkogo Entomologicheskogo Obshchestva 78, 48-83 (2007).

35. Kuznetsov, V.I., "Family Gracillariidae," in Key to Insects of the European Part of the USSR. Lepidoptera, Vol. 4 (2), Ed. by G.S. Medvedev (Nauka, Leningrad, 1981), pp. 149-311 [in Russian].

36. Kuznetsov, V.I. and Baryshnikova (Seksyaeva), S.V., Brief Catalogue of Miner Moths of the Family Gracillariidae (Lepidoptera) of the Fauna of Russia and Adjoining Countries (St. Petersburg, 1998) [in Russian].

37. Kuznetsov, V.I. and Baryshnikova, S.V., "Brief Review of Mining Moths of the Genus Parornix Spuler, 1910 (Lepidoptera, Gracillariidae) of the Palaearctic Fauna," Entomologicheskoe Obozrenie 82 (1), 116-137 (2003).

38. Legalov, A.A., "Annotated List of Species of Superfamily Curculionoidea (Coleoptera) from the Asian Part of Russia," Amurskii Zoologicheskii Zhurnal 2 (2), 93-132 (2010).

39. Leppänen, S., Altenhofer, E., Liston, A.D., and Nyman, T., "Phylogenetics and Evolution of Host-Plant Use in Leaf-Mining Sawflies (Hymenoptera: Tenthredinidae: Heterarthrinae)," Molecular Phylogenetics and Evolution 64, 331-341 (2012).

40. Lopez-Vaamonde, C., Agassiz, D., Augustin, S., De Prins, J., De Prins, W., Gomboc, S., Ivinskis, P., Karsholt, O., Koutroumpas, A., Koutroumpa, F., Laštůvka, Z., Marabuto, E., Olivella, E., Przybylowicz, L., Roques, A., Ryrholm, N., Šefrová, H., Šima, P., Sims, I., Sinev, S., Skulev, B., Tomov, R., Zilli, A., and Lees, D., "Lepidoptera," BioRisk Biodiversity and Ecosystem Risk Assessment 4 (2), 603-668 (2010). 
41. Magurran, A.E., Measuring Biological Diversity (Blackwell Publishing, Oxford, 2004).

42. Mutanen, M., Kaila, L., and Tabell, J., "Wide-Ranging Barcoding Aids Discovery of One-Third Increase of Species Richness in Presumably Well-Investigated Moths," Scientific Reports 3, 2901 (2013), doi:10.1038/ srep02901.

43. Proctor, J.T.A., Bodnar, J.M., Blackburn, W.J., and Watson, R.L., "Analysis of the Effects of the Spotted Tentiform Leaf Miner (Phyllonorycter blancardella) on the Photosynthetic Characteristics of Apple Leaves," The Canadian Journal of Botany 60, 2734-2740 (1982).

44. Raimondo, F., Ghirardelli, L.A., Nardini, A., and Salleo, S., "Impact of the Leaf Miner Cameraria ohridella on Photosynthesis, Water Relations and Hydraulics of Aesculus hippocastanum Leaves," Trees 17, 376-382 (2003).

45. Ratnasingham, S. and Hebert, P.D.N., "BOLD: The Barcode of Life Data System (http://www.barcoding life.org)," Molecular Ecology Notes 7, 355-364 (2007).

46. Rougerie, R., Kitching, I.J., Haxaire, J., Miller, S.E., Hausmann, A., and Hebert, P.D.N., "Australian Sphingidae: DNA Barcodes Challenge Current Species Boundaries and Distributions," PloS One 9 (7), e101108 (2014).

47. Šefrová, H. and Laštůvka, Z., "Do Invasive Species of Lepidoptera in the Czech Republic Share Traits Favoring Introduction and Invasion?" Neobiota 8, 87-99 (2009).

48. Selikhovkin, A.V., Denisova, N.V., and Timofeeva, Yu.A., "The Population Density Dynamics of Mining Moths in St. Petersburg," Izvestiya Sankt-Peterburgskoi Lesotekhnicheskoi Akademii 200, 148-159 (2012).

49. Stroganova, V.K., "Materials on the Fauna of Sawflies Mining the Birch in Western Siberia," in The Fauna of Siberia: Proceedings of the Biological Institute of the Siberian Branch of the USSR Academy of Sciences, Vol. 16 (Nauka, Novosibirsk, 1973), pp. 120-125.
50. Tarasova, O.V. and Sanina, I.V., "The Species Richness of Mining Insects on Deciduous Plants in Krasnoyarsk and Its Environs," Vestnik Krasnoyarskogo Gosudarstvennogo Universiteta. Seriya Estestvennye Nauki 7, 45-48 (2004).

51. Tarasova, O.V., Kovalev, A.V., Sukhovolsky, V.G., and Khlebopros, R.G., Phyllophagous Insects of Urban Plantations: Species Composition and Abundance Dynamics (Nauka, Novosibirsk, 2004) [in Russian].

52. Tibatina, I.A., "Materials on the Fauna of Some Microlepidoptera Damaging the Birch in Western Siberia," in The Fauna of Siberia (Nauka, Novosibirsk, 1970), pp. 202-221 [in Russian].

53. Tibatina, I.A. and Stroganova, V.K., "On the Biology of Two species of Leaf Miners Damaging the Birch in Western Siberia," in Fauna and Ecology of Arthropods of Siberia (Nauka, Novosibirsk, 1966), pp. 63-65 [in Russian].

54. Tomilova, V.N., "The Insect Fauna of Green Plantings of Irkutsk," Entomologicheskoe Obozrenie 41 (1), 125-141 (1962).

55. Tomilova, V.N., "Leaf Mining Insects of Eastern Siberia," in The Fauna and Ecology of the Insects of Eastern Siberia and the Far East (Irkutsk, 1973) [in Russian].

56. Vstovskaya, T.N. and Koropachinsky, I.Yu., Woody Plants of the Central Siberian Botanical Garden (Siberian Branch of Russian Academy of Sciences, Novosibirsk, 2005) [in Russian].

57. Wagner, D., DeFoliart, L., Doak, P., and Schneiderheinze, J., "Impact of Epidermal Leaf Mining by the Aspen Leaf Miner (Phyllocnistis populiella) on the Growth, Physiology, and Leaf Longevity of Quaking Aspen," Oecologia 157 (2), 259-267 (2008).

58. Yanovsky, V.M., Forest Entomofauna of SayanoShushensky Biosphere Reserve (Krasnoyarsk, 1996) [in Russian].

59. Yanovsky, V.M., Phyllophagous Insects on the Birch and Aspen in Siberian Forests: a Manual (Krasnoyarsk State University, Krasnoyarsk, 2003) [in Russian]. 